\title{
Se não o sim, o quê? (Uma análise do filme Party, de Manoel de Oliveira)
}

Celia Cavalheiro Centro Universitário Senac - Audiovisual

"O mar é das gaivotas/ que nele sabem voar..."

Leila Diniz

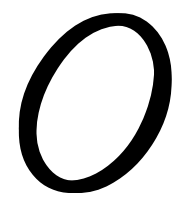

Tejo deságua em Lisboa, o Douro deságua no Porto. "O rio da minha aldeia", como queria Fernando Pessoa; o "porto da minha infância", eternizado por Manoel de Oliveira. Portugal é a terra da memória, os rios que contornam suas cidades, mais o oceano reprisando para o futuro suas conquistas, colônias, histórias de um tempo de domínio, depois, recolhimento. Paisagem propícia ao estado de melancolia, mas também à liberdade de sentimentos, pois, se tudo é fugaz, fazse premente anunciar a boa nova vinda da fluidez das águas, nada nunca permanecerá o mesmo, lição antiga, o tédio aqui não terá lugar. Mas é exatamente esta nuance de sensações que vai abrigar maneiras diferentes de se contar histórias. Entre a melancolia e a alegria reconquistada, está o espaço da narrativa.

E a escritora portuguesa Agustina Bessa-Luís, sabe muito bem lidar com este espaço onde as lembranças vão reavaliando conceitos, entrecortando falas, antes decisivas, para dar um novo formato à existência. É desta maneira, através de um otimismo sempre só insinuado, que sua escrita entra em 
perfeita sintonia com as imagens cuidadosamente delineadas pelo cineasta Manoel de Oliveira. Foram várias as adaptações do diretor dos textos da romancista, sempre mantendo um entendimento quanto ao que se pretende mostrar, ou provar, sobre as controvérsias dos sentimentos humanos, numa linha tênue entre, não o real e a ficção, como é comum afirmar, mas entre a possibilidade de afirmar a realidade dos sentimentos e a fugacidade deles perante o próprio real. Os personagens vão se apresentando, independentemente da trama na qual estão envolvidos, através de uma fala sincopada que se enquadra perfeitamente no cenário, como a última peça de um quebracabeça, onde reside a não ação e o gosto por tudo que aos poucos pode ser revelado.

Tamanha é a conjunção entre os diálogos escritos por Agustina Bessa-Luís para os filmes de Manoel de Oliveira que podemos atestar uma continuidade de intenções, uma confluência de motivos para a composição de uma narrativa de situações, ao invés do desenrolar temporal de uma história. É assim mesmo em Vale Abraão (adaptação livre da escritora do romance Madame Bovary, de Flaubert), onde a construção da personagem chave não se dá pela continuidade dos fatos, mas pela conformação de sua personalidade aos fatos que correm; ela permanece sempre a mesma, observando os acontecimentos, como uma cientista, porém distante e distraída. E é este movimento de especulação das possibilidades que alinhava a narrativa, também de situações, do filme Party, de 1995.

O tema de Garden Party dos Açores, com roteiro e argumento de Manoel de Oliveira e diálogos encomendados a Agustina Bessa-Luís, é, como afirma o próprio diretor, o do confronto entre o masculino e o feminino, numa tentativa de mostrar o que há de sincero e, também, perverso nas relações, e o que se pode esperar, ou não, da condição intrínseca a cada sexo. $\mathrm{O}$ argumento, de fato, é simples: dois casais, que se encontram de quando em quando, testam a sua capacidade de sedução e, por 
tabela, a capacidade de resistência à traição. O primeiro casal, que recebe o outro - recebe no sentido de acolher, reportar para dentro de sua intimidade - é formado por Leonor (Leonor Silveira) e Rogério (Rogério Samora), moradores de um castelo na Ilha de São Miguel, em Ponta Delgada, nos Açores. Casal pertencente a uma espécie de nobreza em extinção e que comemora, no primeiro tempo da narrativa, dez anos de casamento. O outro casal, os intrusos, por assim dizer, é composto por Irene (Irene Papas) e Michel (Michel Picoli), ela, atriz e empresária do mundo das artes; ele, um bon vivant, no limite do vazio da própria existência. O filme é dividido em duas partes, a primeira se passa no jardim do palácio, durante a festa comemorativa do aniversário de casamento, e a segunda, cinco anos depois, num jantar íntimo na suntuosa sala de estar, quando o excêntrico casal é novamente convidado para um fim de semana na Ilha.

Os diálogos são pautados por uma reflexão inicialmente frívola sobre o encanto das mulheres, o desejo e a possibilidade do adultério quase como um apêndice da vida matrimonial. A certa altura o personagem do velho (Michel), cuja fala é um misto de erudição e ironia, afirma: "Quem seduz conspira contra a ordem das coisas", estabelecendo, a partir daí, a importância muito maior que há na renovação da ordem, do que no próprio ato de traição. Seduzir significa mudar as cores da paisagem; concretizar a traição é entornar o balde, confundindo toda a pintura, ou seja, a traição consumada seria o excesso desnecessário. Sendo assim devemos considerar se o tema desta narrativa será mesmo o confronto entre o masculino e o feminino e uma divagação sobre as questões do amor.

Aprofundando então um pouco mais a idéia da narrativa de situações, talvez o filme possa ser dividido em três partes, ao invés de duas, sendo a primeira a sequência, que antecede a festa, quando a mulher sugere ao marido que fujam, que não participem da própria comemoração e ele, sem levá-la a sério 
- ou sem perceber-lhe o real desejo - responde "fugir para onde? Estamos numa ilha, fugir aqui significa emigrar!". Pondo um fim ao, talvez, único esforço de felicidade da esposa e à demonstração sincera de seu amor inabalável por ele. Resignada, Leonor sobe as escadas do jardim para se vestir; na cena seguinte, ela chega à festa com um vestido curto demais para a ocasião, evocando suajuventude e capacidade de sedução: a personagem representa, portanto, a necessidade premente de mudar as coisas, de transgredir. Desta forma, são três os momentos da narrativa, entendendo que esta abertura é o prenúncio, não de uma história de confronto amoroso, mas de inquietude e vazio. São situações que se colocam sem nenhuma correspondência com o tempo real, exceção feita à imposição da data que introduz a parte final, cinco anos se passaram. Após cinco anos, por insistência da esposa, Rogério convida novamente o casal para ir visitá-los, cinco anos que não significarão nada diante da imposição de eternidade, que exala das peças que compõem o ambiente, pela antiguidade da construção, os afrescos, o peso do mármore nas estátuas.

Após um jogo nonsense na cena dojantar onde os personagens precisam fazer um certo contorcionismo para se verem (há uma enorme escultura de um peixe no centro da mesa, não há comida, nem taças de vinho, e o jantar é rejeitado pela convidada, como num recurso de farsa teatral, onde só os diálogos importam), eles abandonam a mesa já arrependidos daquele encontro desastroso, e, na sala ao lado, observam a lareira que, como explica o proprietário, "é do tempo em que havia sabedoria, e não ciência". O sofrimento represado no olhar do anjo esculpido, a austeridade no olhar do clérigo na pintura, tudo atesta uma racionalização dos sentimentos, tudo flui para um entendimento da situação, para a aceitação das perdas, pois elas já se haviam anunciado cinco anos atrás, e este seria o momento da consumação do ato. 
Isto se, realmente, fosse a composição de um quarteto amoroso, envolvido pelo verdadeiro sentimento que "desorienta o homem", como anuncia, de maneira insistente, o velho ao falar do sentimento que nutre pela amiga. Mas estes quatro personagens não estão desta maneira disponíveis. Num segundo olhar pode-se descrevê-los de maneira menos complexa ebem mais humana: Leonor, uma mulher sem nenhum sentimento, apesar de mecanicamente explorá-los, revela-se numa das frases finais, em relação aos apelos do amante 'em potencial': "Eu não o amo, mas como ele me ama, estou à sua disposição." Por isto ela passou cinco anos pensando nele, porque seu amor representava a possibilidade de mudança na ordem daquela existência enclausurada, como nos corredores de um museu. $\mathrm{O}$ velho homem, colecionador de teorias, que dispara todo tempo palavras sobre a extraordinária condição humana é, ele próprio, o mais vulgar - ordinário - dos quatro, por causa do amor que sente, mas não ousa provar: "Sinto que sua presença constrange meu amor".

Na outra ponta o marido, traído desde sempre pela acentuada ausência no olhar da esposa e pelo arranjo perfeito que criou para os dois, sem nunca questionar os efeitos: "Estou casado há quinze anos e o hábito me impede que se deseje o fruto proibido", contracenando com aquela mulher singular, atriz, empresária, símbolo da modernidade, o feminino no mundo dos homens - mas que tem medo.

Portanto, o argumento de Manoel de Oliveira busca uma comunicação entre intenções, um acerto de contas que resulte, com sorte, numa relação amorosa, na permanência dos bons sentimentos. Isto é revelado por diálogos não tão inocentes ou delicados, ditados por Agustina Bessa-Luís, que, como é de seu feitio não facilitar as coisas, mas, antes, torná-las ásperas (porque áspera é a vida), acaba por travar um confronto onde o espectador deve tomar partido. Insistimos, pois, na fala, já citada, do personagem Michel, o velho: 
"Eu disse que vim para levá-la, mas é mentira."

"Meu amor não precisa de você.."

"Sinto que sua presença constrange o meu amor."

Ao final, sentencia:

"Não se começa outra vida, é sempre a mesma."

Fala esta conclusiva, afinal, pois apesar de introduzir um esboço das falhas humanas e a perversidade que há em se autodenominar conhecedor das coisas e do amor - traduzida pela serenidade com a qual faz esta declaração - temos a complacência espelhada na personagem feminina, em compreensiva espera do homem redentor, representada aqui num Dom Juan reflexivo (o que por si só já é uma incoerência). Redentor de sua felicidade, de seu desejo, de sua condição mesma de ser mulher, ele certamente a trairá, declinando seu desejo de tê-la só para si, autodenominando-se culpado pelo infortúnio causado, ele opta pela abnegação. Este amor é o único sustento de sua precária existência, realizá-lo é perdê-lo para a banalidade de uma vida plena de envelhecimento.

Confronto instaurado, escolhemos - espectadores já um tanto acuados - escapar de todas essas armadilhas, voltar para a via onde os acontecimentos nem sempre são tão previsíveis. Pois esta é a verdadeira traição, nos colocarmos à beira de um destino incontestável, enquanto brincamos de seres únicos e extraordinários. Mas, nem a escritora, nem o diretor tomaram realmente este partido, no desfecho da história, ou na última situação desta narrativa, a normalidade é re-instaurada pela conquista da felicidade que, fica claro, nada tem a ver com a troca de casais ou fuga para uma nova vida, "que não há". Ao revelar sua condição de arruinado financeiramente, a esposa, de mala na mão e debaixo de um temporal, volta para o marido um verdadeiro sorriso de satisfação. Os planos para o futuro 
brotam de sua boca como se nunca antes ela tivesse participado daquele ensaio de martírio em busca de um, batido, sentido da existência. As possibilidades se abrem, eles podem, de agora em diante, trabalhar organizando festas para outros casais, e não protagonizá-las, vender tudo e viver numa casa simples, sem o peso da eternidade, da cultura, dos gestos contidos.

Pois então, não era mesmo uma história de amor, mas uma narrativa sobre o tédio da burguesia, dos intelectuais, dos artistas ensimesmados na admiração de si mesmos. O tédio da profundidade, da reflexão, do excesso de tentativa de conhecimento sobre o belo. Tudo isto salvo por planos de trabalho, pelo recomeço, pela mão de obra, pelo sustento da família. Ou melhor, pela sustentação de um amor que se perdia no ócio do bom gosto e refinamento. Um alegre dizer sim para o ganha pão de cada dia.

Um filme engajado talvez muito mais do que a dupla formada pela escritora e pelo cineasta gostaria de escancarar. A intenção primeira da narrativa pode ser mesmo a da composição do amor e a revelação das imperfeições humanas - e não exatamente o contorno crítico da sociedade - mas, que imperfeição maior do que a não aceitação da realidade? Este é o retrato dado pelo trânsito dos estranhos casais da narrativa, entediados com a fragilidade de seus sentimentos, com a pouca emoção, com a quantidade enorme de recusas ao tal fruto proibido, não podem mudar o que não aceitam como real: a banalidade de suas vidas.

Em entrevista a Leon Cakoff ${ }^{1}$ o diretor Manoel de Oliveira fala de sua prisão sob o regime salazarista e atesta que aquela experiência lhe causou um profundo "conhecimento: o do tédio". Ficou, desde então, com a "impressão de que o salazarismo era a expressão do tédio" e, destas lembranças, ele fez o filme

${ }^{1}$ CAKOFF, 2005, p. 74. 
Visita ou Memórias e Confissões (1982), onde incluiu um texto de Agustina Bessa-Luís, oferecido por ela. Portanto, este diálogo já começa lá atrás, numa conversa reincidente sobre o veneno da humanidade, aquilo que impede homens e mulheres de se relacionarem, sobre a prepotência humana que forja caminhos certeiros para a não comunicação, não realização dos sentimentos, desprezo pelas coisas pequenas e simples, pelo cultivo da memória e afirmação de um povo.

Quanto ao tema inicial, introduzido como epígrafe pela canção grega:

Já te disse e digo outra vez

à beira do mar é preciso cuidado.

À beira do mar revolto as ondas

vão-te apanhar e tu vais-te perder.

Nosso cuidado talvez deva ser outro, o perigo é o da calmaria, como dita uma antiga canção nossa comparando o mar ao vai e vem do amor, ${ }^{2}$ o perigo é mesmo o tédio. Agustina Bessa-Luís e Manoel de Oliveira, em antiga parceria, já hoje não mais em andamento, construíram uma história onde os laços e as

${ }^{2}$ Composição de Sueli Costa e Cacaso:

"Quando o mar tem mais segredo

Não é quando ele se agita

Nem é quando é tempestade

Nem é quando é ventania

Quando o mar tem mais segredo

É quando é calmaria.

Quando o amor tem mais segredo

Não é quando ele se arrisca

Nem é quando ele se ausenta

Nem quando eu me desespero

Quando o amor tem mais perigo

É quando ele é sincero." 
tradições, tão caros ao povo português, perdem-se numa efusão de necessidade de futuro, continuidade, modernidade. Mas, sendo impossível perder-se completamente da trama das tradições, mostram a saída pela revolução transcendental, que há na decisão pelo trabalho. O trabalho em si e o trabalho visceral que há em mudar a ordem das coisas.

\section{Referências bibliográficas}

BESSA-LUIS, Agustina. Garden Party dos Açores. Lisboa: Guimarães, 1996.

CAKOFF, Leon. Entrevista com Manoel de Oliveira. In: MACHADO, Alvaro (Org.) Manoel de Oliveira. São Paulo: Cosac Naify, 2005.

OLIVEIRA, Manoel de. Garden Party dos Açores. Portugal-França, 1996. Roteiro de Manoel de Oliveira e diálogos de Agustina Bessa-Luis.

\section{Resumo}

Este artigo procura fazer uma análise dos diálogos do filme Garden Party dos Açores, de Manoel de Oliveira, escritos por Agustina Bessa-Luis.

\section{Résumé}

Cet article a pour but une analyse interprétative des dialogues du film Party de Manoel d'Oliveira écrits par l' écrivain Agustina Bessa-Luis. L'objectif principal est de montrer que par une mise en scène élaborée pour causer un effet de recherche avec le spectateur à propos des angoisses des personnages, le récit révèle finalement la nécessité de transformer la condition humaine. 